\section{Undskyld, men hvor ligger Jesus begravet?}

\author{
Af Kjeld Koplev
}

Min tese - eller som det vel hedder nu om dage, min pointe - er, firkantet og skåret ud i pap, at i dagens Danmark er det ikke historikerne men journalisterne der skriver historien. Den aktuelle historieskrivning er, så vidt jeg kan skønne, i dag gledet de professionelle historikere af hænde. Historieskrivningen er i stedet overtaget af journalister, og endda af temmelig tilfældige journalister. Med alt hvad det indebærer. På godt, men, efter min mening, bestemt mest på ondt. Og det er efter min mening - eller kan i hvert tilfælde vise sig at være - en ganske farlig udvikling. En udvikling der ikke synes nem at ændre, at styre eller dæmme op for. Snarere tværtimod.

Det ser ud som om journalisternes indflydelse, mediernes omfang og ikke mindst deres dominans tager til i disse år. Og det er en proces som, set i lyset af dagens emne om hvem der har fat i den lange ende når det gælder historien i samfundet, kan vise sig at være ganske uhensigtsmæssig. Eller i det mindste en proces man skal have øjnene åbne over for. Og her er det ganske godt at erindre sig PH's advarende ord om: at udviklingen altid og til alle tider kommer af sig selv, mens det tilsvarende altid, og alle steder, kniber betydeligt mere med fremskridtet.

Det betænkelige ligger $i$, at journalisterne, som jo i øvrigt, ganske modsætningsfyldt må jeg sige, i befolkningens øjne ikke har nogen troværdighed - man behøver blot at studere disse troværdighedsbarometre som jævnligt offentliggøres, for at konstatere at disse målinger altid og uomtvisteligt viser at journalister konkurrerer heftigt med politikere om sidstepladsen - i højere og højere grad kommer til at dominere historieskrivningen. For på trods af den ringe troværdighed, så er de selvsamme journalister uomtvisteligt ved, viser det sig, på mange måder at overtage historikernes rolle som forvalter af den offentligt tilgængelige historie og meget ofte gør de det alene af den grund at de har adgang til medierne. Og de - eller rettere vi, for nu ikke at stå her og spille alt for hellig - gør det uden på nogen måde at have nogen form for kompetence til det. Tilmed gør vi det uden overhovedet at have nogen uddannelse der hjemler os retten til at tage historien ved vingebenet og fortolke den for en større offentlighed. Denne nonchalance kan, mener jeg, i længden være uhyre farlig for historieforståelsen i Danmark. Og her skal jeg ikke komme med alle fraserne om vigtigheden af at kende historien, stå ved sine rødder osv., men sådan set bare sige at det i mine øjne er farligt alene af den grund at den historiske hukommelse med tiden kan risikere at blive lige så kort som den journalistiske. Vel vidende at en journalistisk hukommelse som hovedregel kun strækker sig frem til næste dags historie i avisen, i 
radioen, i tv. Time Magazine beskrev det for et par år siden ganske præcist med ordene: „Historieskrivning uden hukommelse“.

Dette skred er også farligt set i lyset af at journalister er et meget skrivende folkefærd, men ikke tilsvarende et meget læsende folkefærd. Det tror jeg såmænd ikke engang standen selv vil prale af. Der hersker en ikke ringe grad af despekt for bøger og måske især for teoretisk viden inden for mit fag. Og der var da heller ingen der modsagde historikeren Jes Fabricius Rasmussen der for nyligt ganske spydigt skrev i en aviskronik: At man kan ikke forlange af journalister at de læste bøger, men måske nok, at de i det mindste læser aviser - og måske som mindstemål læser deres egne også selv om de så skulle gå et år eller to tilbage i tiden.

Jeg synes derfor man uden blusel kan tale om journalistikkens ulidelige lethed som en trussel mod historieforvaltningen. Specielt i lyset af, at det i dag, tiere og tiere i menigmands øjne er journalisterne der i offentlighedens øjne skriver historien - og gør det med stort $\mathrm{H}$.

Pudsigt nok kommer netop en historiker til at levere en slags bevis for rigtigheden af min påstand om journalistikkens ulidelige lethed. I hvert tilfælde mener Bent Blüdnikow tilsyneladende at man kan slippe lettere om ved sine udsagn ved at kalde sig journalist $\mathrm{i}$ stedet for historiker, sådan som han har gjort det i vist nok sin seneste bogudgivelse. Og givetvis har han ret. Desværre. Meget som ikke ville være gået i faghistorikernes verden, kan man slippe om ved i den journalistiske.

Men alligevel: det er journalisterne der skriver historien.

Sådan burde det selvsagt ikke være. Med en større grad af ansvarlighed burde letkøbtheden være bandlyst begge steder.

Bertold Brecht lader en af sine personer sige: Jeg er en stor modstander af aviserne. Jeg vil have dem forbudt. Hvortil Brechts alter ego, Hr. Keuner svarer: Jeg er en endnu større modstander: Jeg vil have nogle bedre aviser.

Et andet eksempel på journalistikkens ulidelige lethed oplever vi i disse dage med forlaget Høst og Søns billedbog om Frikorps Danmarks fremfærd under 2. verdenskrig. Bogen blev trukket tilbage efter at der var sået tvivl om mange af billedteksternes korrekthed. Jeg skal ikke dømme eller bedømme. Det er jeg ikke kompetent til. Men det interessante for min tese eller pointe - er at billedredaktøren, den ansvarlige for billedteksterne, en journalistisk kollega, udtalte til Politiken: At nu skulle man huske på, at det her jo ikke var en fagbog, men et journalistisk værk. At han dermed fældede dom over vort fag er én ting. Noget andet er at han på sæt og vis også demonstrerede en voldsom despekt for historieskrivningen. Men ikke nok med det: Heller ikke i andre henseender holder forklaringen vand. For Fru Jensen eller Hr. Petersen der køber forlagets Høst og Søns billedbog om Frikorps Danmark vil den til alle tider fremstå som netop en historiebog. Det er derfor de køber den. De anskaffer sig den tilmed ganske konkret af historisk interesse. 
At det så i samme åndedrag blev fremhævet at billedbogen ikke var blevet til for at tjene penge, men fordi det var en nødvendig bog, virkede næsten pinligt. Ikke mindst i lyset af at RUC-folkene Claus Bundgård Christensen, Niels Bo Poulsen og Peter Scharff Smith med deres Under Hagekors og Dannebrog har leveret mere end 500 siders dokumentation for danskeres fremfærd i Waffen SS under 2. Verdenskrig. Og vel at mærke gjort det i en velskreven og let læst bog der er blevet købt af så usædvanligt mange som 11.500 danskere. Så nødvendig var Høst og søns billedbog dermed næppe.

Og som sagt er det journalisterne der skriver historien.

Men lad mig også tage fat i en anden ende. Den engelske historiker Eric Hobsbawm fortæller, at han skrev sin historie om det ekstreme århundrede bl.a. på baggrund af en forespørgsel fra en af de højt begavede historiestuderende på Hobsbawms universitet. Studenten opsøgte ham efter en forelæsning. Han så ham frank og frejdigt lige i øjnene og sagde så: Det at De professor Hobsbawm hele tiden taler om en 2. verdenskrig - indikerede det, at der havde været en 1.?

Umiddelbart var jeg tilbøjelig til at kalde det et ualmindeligt dumt spørgsmål. En af den slags kun en amerikansk student kunne finde på at stille. Faktisk slog vi os på lårene af grin første gang vi læste det. Ha, ha, ha, hvor er de amerikanere dog dumme og uvidende. Var det ikke det vi altid havde sagt osv. osv. Men ved nærmer eftertanke kom jeg faktisk til den næsten stik modsatte konklusion. Man kunne også vælge at betragte studentens registrering af det der med den 2. verdenskrig, som udtryk for at her stod professor Eric Hobsbawm over for en videnskabsmand i svøb. Professor Hobsbawm taler hele tiden om 2. verdenskrig. Studenten undrer sig, der sniger sig en spørgende tvivl ind $i$ hans sind. Der er et eller andet med det der den 2. som hele tiden dukker op. Den 2. verdenskrig, tænker han. Professoren taler om en 2. Betyder det at der har været en 1.? Ergo måtte studenten, som en sand forsker, have ryddet tvivlen af vejen. Han må have rede på om det dækkede over noget - og i dette tilfælde altså om der havde været en 1. verdenskrig som lå forude for denne den 2. Den som professor Hobsbawm hele tiden talte om. Og han far jo svar. Han finder en sandhed. Han bliver klogere og hindret $i$ at gøre den fejltagelse det ville være at gå uvidende ud i verden om emnet 1 . verdenskrig.

Og så lige til min pointe: Jeg er ikke slet så sikker på, for nu at sige det mildt - at en journalist havde spurgt om det samme, havde været plaget af samme tvivl som studenten var det i denne situation. Journalisten ville have noteret sig - på et pressemøde f.eks. - at manden der oppe, ham den vist nok berømte professor som han var sendt hen for at dække, for at referere, talte meget om 2. verdenskrig - og det ville han så skrive. Journalisten ville nok ukritisk have slugt det professoren fortalte ham på pressemødet/forelæsningen. Hvorfor kere sig om noget man måske ikke rigtigt forstod. Den 2. ville have været godt nok til ham. 
Og det er journalisterne der skriver historien.

Som med 2. verdenskrig kontra den 1. var der ingen journalist der under optrapningen af Irak-krigen så meget som tøvede med at videregive oplysningerne om at Saddam Husseins soldater havde revet 300 kuwaitiske børn ud af deres kuvøser og smidt dem på gulvet på hospitalets fødeafdeling. 300 ?

Havde nogen af os tænkt os om, havde vi talt efter og havde vi sat tallet i forhold til befolkningsmængden i landet - foretaget en kontrolopringning til f.eks. en fødselslæge på Rigshospitalet i København - så ville enhver idiot, eller næsten enhver idiot formentlig, kunne regne ud, at så mange kuvøsebørn var der overhovedet ikke i selv denne meget olierige og meget pengerige stat. Men ingen tøvede på pc'eren af den grund. (At historien så endda viste sig at være pure løgn, opdigtet af PR-firmaet Hill $\&$ Knowlton og produceret for kuwaitiske oliepenge er så en anden og langt mere pinlig sag).

Den danske tv-journalist der under Kosova-konflikten berettede om at amerikanerne nu havde bombet det serbiske indenrigsministerium, fordi her lå den kommandocentral som styrede de serbiske troppers bevægelser inde i Kosovo, men at NATO havde bombet om natten så ingen ville blive dræbt - ja, han lod heller ikke mange tanker løbe gennem hovedet før han føjede sit bidrag til verdenshistorien. For i al sin enkelhed må et af udsagnene i hans og NATO-kildens beretning være usand. Enten var der ikke tale om noget krigs- hovedkvarter. Eller også blev der dræbt mennesker. Og journalisten ville have opdaget det, hvis han ikke havde været journalist. For: Hvis der virkelig var tale om at den bombede bygning husede en kommandocentral så lukker en sådan næppe klokken 16 om eftermiddagen. Krig er et 24-timers foretagende. Ergo fungerer et krigshovedkvarter hele døgnet igennem. Ellers måtte sandheden være, at der rent faktisk blev dræbt mennesker under bombardementet. Men den historieskrivende journalist anså det ikke for sin opgave at tænke sig om, eller at afprøve NATO' s sandhed i den historiske sandheds tjeneste.

Jeg havde oprindeligt tænkt mig at kalde indlægget her: Undskyld findes der en første verdenskrig, med henvisning til fortællingen om Hobsbawms historiestuderende. Nu blev det i stedet til: Undskyld, hvor ligger Jesus begravet. Og det skyldes et af de mange andre tilfælde hvor jeg har observeret hvordan historien drastisk skrider i den journalistiske formidling. Nogle gange, som under konflikten i Bosnien, Kosova eller Kuwait, sker det med næsten katastrofale følger. Andre gange er der kun tale om kuriøse tilfælde, som da et tvkamera panorerede ud over Jerusalems omegn, passerede en kirke og journalisten med fasthed i stemmen proklamerede: Her ligger Jesus begravet. Så vidste danske tv-seere det. At han i farten kom til at kalde kirken Gravkirken eller rettere Den hellige Gravs kirke for Genopstandelseskirken er en petitesse i forhold til at han her med et rask journalistisk snuptag rev grundlaget væk 
under kristendommen og i samme åndedrag vel næsten kom til at fornægte Guds eksistens.

Men det rykker hele tiden. I en tv-serie fornylig var vi med mediet gæst på en lang række danske herregårde. Bl.a. også på Børglund Kloster. Og fortælleren fortalte at herfra stammede Michael Rotbøll, den første dansker i britisk tjeneste der blev skudt under 2. verdenskrig. Desværre blev det fremført at Michael Rotbøll, som var britisk faldskærmsmand, blev skudt - nå, ja, selvfølgelig - af tyskerne. Den del af de mere end 1 million seere der så udsendelsen og som ikke er gamle nok til selv at have oplevet besættelsen af Danmark eller de der ikke har en eksakt historisk viden, ved nu, at Michael Rotbøll blev skudt af tyskerne. For det har de selv sagt i tv. Og som tyskerne siger: Alles ist war, was geschrieben ist. Eller omsat til 1999 IT-dansk: Alt hvad der vises i tv er sandt. At det i den historiske verden så var dansk politi der skød ham har måske også kun betydning for historikere og historisk interesserede. Og i hvert tilfælde kan tv-produceren beroligende sige at den forkerte historiske oplysning ikke forrykker tv-udsendelsens underholdningsværdi.

\section{Man kunne også tage en} anden og måske alvorligere sag - en ganske gammel kæphest, der dokumenterer, at når journalister løber i flok, er det altid sandheden - og dermed også den historiske sandhed - der er den sikreste taber. Jeg taler om den myte der går under fællesbetegnelsen: Massakren på Den Himmelske Freds Plads. En myte der dækker over nedkæmpelsen af demokratibevægelsen i maj 1989 i den kinesiske hovedstad Beijing. Denne myte dukker op og op og op og op igen og igen og igen til trods for at mange gode kræfter har forsøgt at mane den i jorden. Blandt mange andre har et forskerhold fra Harvard University produceret og udgivet et kæmpearbejde der dokumenterer fraværet af massakren. De har opsøgt og talt med samtlige mediefolk, samtlige, der var på pladsen hin nat. Og ja, der blev slået kinesere ihjel, ingen tvivl om det. Men ikke i de mængder dagspressen eksellerer i. Og slet ikke på Den Himmelske Freds Plads. Alligevel har den historiske sandhed ikke nogen jordisk chance over for den journalistiske. Den journalist der natten efter nedkæmpelsen af demokratibevægelsen kunne fortælle om ikke mindre end 10.000 døde på Den Himmelske Freds Plads - de må have fyldt godt sammen med den ene million demonstranter han også fik placeret i Beijings centrum - skrev enten mod bedre vidende, og det tror jeg ikke, eller fordi han ikke vidste bedre. Og det er vel det farligste.

Og der er masser af andre eksempler på at det historiske i disse år kommer til kort over for det journalistiske. Og det gjorde måske ikke så meget, hvis det ikke lige netop var fordi journalistikken på mange måder i vores tvalder har forladt sin position som den 4 . og såkaldt kontrollerende statsmagt for $\mathrm{i}$ stedet at begive sig ind på underholdningsmarkedet, hvor nyheder er blevet en mere direkte salgsvare, en vare der skal fange og fænge seerne så de høje seertal bevares til glæde for de politikere 
der skal bevillige licensen eller de firmaer der skal betale for reklamerne.

De tider hvor den finske medieforsker Kaarle Nordenstreng kunne rejse rundt og forlæse for os journalister at det sandelig var vores fornemste job, via bl.a. nyhedsformidlingen, at arbejde for at ændre folks verdensbillede $i$ en mere realistisk retning, ja, de tider er i det mindste for en tid forbi. Og om de nogensinde kommer igen er en helt anden sag. Man skal være optimist for at tro det.

Eller man kunne også med den tyske forfatter Heinrich Böll sige at det er - eller burde være - journalisternes opgave at afsøge grænselandet mellem forfatningens ord og forfatningens virkelighed.

Man kunne tilmed hævde at vi var sat i medieverden for at sætte vores journalistiske pegefinger på den ømme byld der udgøres af skellet mellem det der rent faktisk står i vore love, og de ting der reelt foregår omkring os i vor hverdag - og hver evige dag.

Men skulle vi leve op til Kaarle Nordenstrengs fordring - for slet ikke at tale om Heinrich Bölls - så kræver det at vi, at journalisterne kender forfatningen, og ikke mindst kender forfatningens historie - og at vi kender den politiske og historiske virkelighed til bunds. Og det gør vi ikke.

Og vi gør det slet ikke via vores uddannelse. Ikke endnu. Man kan kun håbe på at det bliver bedre med en konkurrerende uddannelse fra henholdsvis Odense Universitet - og fra RUC.

Men lige så vigtig som den historiske viden er den politiske hold- ning. Og det er ikke noget med det gamle maoistiske slagord om: Først rød, siden ekspert. Slet ikke.

Men uden en politisk holdning til tilværelsens mange tilskikkelser går det ikke, heller ikke om man har nok så megen historisk viden med sig. Jeg ved godt at vi har vedtaget, hvem vi så end er, at ideologier er noget bras. Men hvis de dermed for tilfældet er afskaffet, disse ideologier, så kommer vi til at indføre dem igen, eller finde på et andet ord for dem. For nok dur: Først rød, siden ekspert, ikke - og har aldrig gjort det. Men det modsatte: Ekspert uden holdning, dur heller ikke. Det ikke at have en holdning til formidlingen af ekspertviden går ganske simpelt ikke. Ikke i længden. Og det ser jeg måske allerklarest hos dagens formidler af historie, hos journalisterne.

\section{$\mathrm{Vi}$ er blevet et rimeligt hold-} ningsløst folkefærd der gnidningsløst glider fra det ene medie til det andet for at udføre rakkertjeneste for den højestbydende. Og i øvrigt lader os bruge og misbruge i langt højere grad end f.eks. fortidens hofnarre, der i det mindste ind imellem turde sige magthaverne imod.

Så min bekymring for hvor Jesus i fremtiden skal ligge begravet eller rettere ikke ligge begravet - skal derfor ses i lyset af et ønske om at historikerne på en eller anden måde tager hånd om også den daglige historieformidling, måske tager hånd om os journalister og sørger for at få et undervisningssamarbejde i stand. På den måde vil læserne, lytterne og seerne i højere grad få glæde af udforskningen af grænselandet mellem forfatningens ord 
og dens virkelighed. Eller kunne måske få nyheder de kan bruge til noget, historiske nyheder som kan ændre deres syn på verden i en måske mere realistisk retning, og kan gøre det i en stadig mere kompliceret dagligdag. Så måske kan vi nå dertil at alle - også journalister - kan få mod til at spørge om den megen tale om en 2 . verdenskrig betyder at der engang har været en 1 . Eller hitte rede i om Jesus nu ligger eller ikke ligger begravet uden for Jerusalem.

I hvert tilfælde håber jeg med disse ord, at have givet blot et lille bidrag til debatten om hvor hunden ligger begravet når vi taler om historien $\mathrm{i}$ samfundet. 